\title{
GEOCHEMICAL CHARACTERISTICS OF THE BISMUTH AND ANTIMONY OCCURRENCE IN SOME COAL SEAMS IN THE LUBLIN COAL BASIN (LCB)
}

\author{
GEOCHEMICZNA CHARAKTERYSTYKA WYSTĘPOWANIA BIZMUTU I ANTYMONU \\ W NIEKTÓRYCH POKŁADACH WĘGLA LUBELSKIEGO ZAGLĘBIA WĘGLOWEGO (LZW)
}

The study included 24 samples of coal with 7 cores, boreholes ( 7 coal seams), made by the Polish Geological Institute in Warsaw at the site of a Chelm field and 6 coal samples taken from 2 decks in the Lublin Coal mine „Bogdanka“ S.A. in LCB. Based on performed tests found generally low levels of Sb and $\mathrm{Bi}$ in coal. In the vertical profile of the LCB contents of $\mathrm{Bi}$ and $\mathrm{Sb}$ in coal generally increases from coal seams younger to older age. Content of $\mathrm{Bi}$ in coal from roof part coal seams is usually higher, and ash content in the coal content of $\mathrm{Sb}$ are generally lower than in the carbon of the middle part decks. The content of $\mathrm{Bi}$ in the lateral coal deposits is unlikely to vary, and the gap in the coal content of Bi between the sampling regions coal do not exceed $1.7 \mathrm{~g} / \mathrm{Mg}$. In contrast gap Sb content in coal on the extent LCB is from $1.7 \mathrm{~g} / \mathrm{Mg}$ of $5.8 \mathrm{~g} / \mathrm{Mg}$. The biggest influence on the content of $\mathrm{Bi}$ and $\mathrm{Sb}$ in coal from the LCB is probably organic matter in which these elements are scattered and do not form their own minerals.

Keywords: Bismuth and antimony, bituminous coal, coal seams, Lublin Coal Basin

Celem artykułu było określenie zróżnicowania zawartości Bi i Sb w węglu LZW oraz określenie roli substancji organicznej w ich koncentrowaniu w węglu. Pierwiastki te należą do bardzo rzadko (Sb) lub w ogóle nie oznaczanych (Bi) w węglu kamiennym ze złóż Polski. Badaniami objęto 24 próbki węgla kamiennego z rdzeni 7 otworów wiertniczych (7 pokładów węgla), wykonanych przez Państwowy Instytut Geologiczny w Warszawie na obszarze złoża Chełm oraz 6 próbek węgla pobranych z 2 pokładów w kopalni Lubelski Węgiel „Bogdanka” S.A. w LZW (Rys. 1).

Na podstawie wykonanych badań stwierdzono, że skład petrograficzny węgla (Tab. 1) jest zbliżony do składu petrograficznego paleozoicznych węgli Europy w makroregionie North Atlantic ( $V t=68 \%$, $L=12 \%, I=20 \%$ ), określonego przez Lopo de Sousa e Vasconcelous (1999). Zawartość witrynitu w badanym węglu jest porównywalna z zawartością tej grupy macerałów w węglu z serii paralicznej $(63,8 \%)$ GZW. Ze względu na refleksyjnośc witrynitu, badany węgiel zaliczono do średnio uwęglonego węgla (typ C) ortobitumicznego. Przeciętna zawartość Bi i Sb w badanym węglu LZW jest w przypadku Bi mała, a w przypadku Sb zbliżona do wartości klarków dla węgla bitumicznego i subbitumicznego (Tab. 2).

* FACULTY OF EARTH SCIENCES, UNIVERSITY OF SILESIA, BĘDZIŃSKA STR 60, 41-200 SOSNOWIEC

** CENTRAL MINING INSTITUTE, PLAC GWARKÓW 1, 40-166 KATOWICE; MAIL: Irog@gig.katowice.pl

1 CORRESPONDING AUTHOR: hr.parzentny@wp.pl 


\begin{abstract}
Zawartość Bi i Sb w węglu ogólnie zwiększa się idąc od pokładów wiekowo młodszych do starszych (Rys. 2). Zawartość Bi w węglu z przystropowej części pokładów węgla jest zwykle większa, a zawartość popiołu w węglu i zawartość Sb w węglu są na ogół mniejsze, niż w węglu z części środkowej pokładów (Rys. 3). Ze względu na małą zawartość Bi i Sb w węglu, potencjalnie najkorzystniejszym do ewentualnego spalania jest węgiel z części przyspagowej pokładu 378. Zawartość Bi w węglu po rozciągłości pokładów jest mało zróżnicowana, a rozstęp zawartości Bi w węglu pomiędzy rejonami opróbowania pokładów węgla nie przekracza 1,7 g/Mg (Rys. 4). Natomiast rozstęp zawartości Sb w węglu po rozciągłości LZW wynosi od 1,7 g/Mg do 5,8 g/Mg.

Na podstawie korelacyjnej zależności, między zawartością Bi i Sb w popiele węgla i w węglu, a zawartością popiołu (Tab. 3) przypuszcza się, że największy wpływ na zawartość w węglu LZW omawianych pierwiastków ma substancja organiczna. To przypuszczenie potwierdziły wyniki rozwiązania funkcji RS, wyrażającej (opisaną wzorem nr 1) zależność zawartości pierwiastka w popiele węgla od zawartości popiołu. Stwierdzono, że 100\% zawartości Bi i 97\% zawartości Sb w węglu pochodzi z substancji organicznej węgla. Obserwacje powierzchni próbek węgla, za pomocą mikroskopu optycznego do światła odbitego i za pomocą skaningowego mikroskopu elektronowego (SEM-EDS), nie ujawniły obecności wtrąceń minerałów Bi i Sb w macerałach, ani domieszek tych pierwiastków w minerałach siarczkowych, siarczanowych, węglanowych i ilastych (Rys. 5). Nie stwierdzono także obecności minerałów własnych Bi i Sb. Przypuszcza się, że Bi i Sb mogą być rozproszone w niektórych macerałach i w minerałach, lecz z powodu przeważającej objętości i masy macerałów w węglu nad substancją mineralną, substancja organiczna ma największy lub wyłączny wpływ na zawartość tych pierwiastków w węglu. Związek pierwiastków z substancja organiczną oceniono jako ogólnie niekorzystny dla środowiska w przypadku wykorzystywania tego węgla do spalania. Omawiane pierwiastki Bi i Sb w zakresie temperatur $327^{\circ} \mathrm{C}-1127^{\circ} \mathrm{C}$ łatwo bowiem ulegają w paleniskach odparowaniu oraz szybko kondensują się i wzbogacają na cząstkach faz pierwiastków litofilnych (K, Ca, Na, Mg, Ti). Dlatego mogą one być łatwo uwalniane do atmosfery w formie lotnych związków, a skondensowane na najdrobniejszych cząstkach popiołu lotnego mogą w atmosferze wchodzić w skład pyłu zawieszonego.
\end{abstract}

Slowa kluczowe: bizmut i antymon, węgiel kamienny, pokłady węgla, LZW

\title{
1. Introduction
}

A large and steadily increasing share of coal from the LCB in total weight of burned coal in Poland, tends to insightful cognition of its geochemical properties. Geochemical tests of coal from LCB began in 1978 in Geological Institute in Warsaw (PIG). They consisted in defining the content (in coal and coal ash) of 25 minor and trace elements (As, $\mathrm{Ba}, \mathrm{Be}, \mathrm{Br}, \mathrm{Cd}, \mathrm{Cl}, \mathrm{Co}, \mathrm{Cr}, \mathrm{Cu}$, $\mathrm{Ga}, \mathrm{Ge}, \mathrm{Li}, \mathrm{Mn}, \mathrm{Mo}, \mathrm{Nb}, \mathrm{Ni}, \mathrm{P}, \mathrm{Pb}, \mathrm{Rb}, \mathrm{Sr}, \mathrm{Ti}, \mathrm{V}, \mathrm{Y}, \mathrm{Zn}, \mathrm{Zr}$ ). The coal came from 12 boreholes drilled by the PIG in Chelm deposit. The results of these studies have been mostly published (Bojakowska \& Pasieczna, 2007; Cebulak, 1983; Cebulak \& Różkowska, 1983; Marczak, 1985; Marczak \& Lewińska, 1982; Marczak \& Parzentny, 1985, 1989; Parzentny, 2009). According to these studies it was found that the greatest variation in the carbon content of the LCB has $\mathrm{Zn}$, and the smallest Mo. The increased content of $\mathrm{V}, \mathrm{Co}, \mathrm{Be}$ and $\mathrm{Mo}$, and a small content of $\mathrm{Cu}, \mathrm{Zn}, \mathrm{Cr}$, and $\mathrm{Pb}$ in the coal was found, in comparision to Clarke for sub-bituminous and bituminous coal. The content of most elements in coal decreases with the depth of the seams. The enrichment of $\mathrm{Ga}, \mathrm{Zn}, \mathrm{Ti}, \mathrm{Ba}, \mathrm{Cr}, \mathrm{As}, \mathrm{Pb}, \mathrm{Mn}, \mathrm{Ge}, \mathrm{Ni}$ and $\mathrm{Rb}$ elements in roof and floor section of seams, or only in roof part of coal seam was obserwed in LCB. The Be, $\mathrm{Cu}$ and $\mathrm{Zn}$ are bonded with organic matter of coal. With a mineral substance, $\mathrm{Li}, \mathrm{Mo}, \mathrm{Cd}, \mathrm{Cr}, \mathrm{V}, \mathrm{Pb}$ and $\mathrm{Zn}$ elements are bonded.

So far the results of geochemical coal from LCB are applicable for prediction of the quality of solid products from coal combustion. The content of elements in coal and their association with organic and mineral matter have in fact a greater impact on their content in fly ash and cinder, than the technical and technological conditions for coal combustion (Xu et al., 2003). The research on 
finding LCB coal - with obtained ash after its burning that is characterized by a high content of elements critical in terms of their possible recovery - is also conducted (Cebulak, 1983; Strugała et al., 2014). The geochemical tests might have an important manner for predicting toxicity of the waste from thermal coal conversion processes and for the possible recovery of elements and of other so far poorly known elements in coal.

The aim of presented work was to determine the diversity of bismuth (Bi) and stibnite ( $\mathrm{Sb}$ ) content in the LCB coal and to define the role of organic matter in their concentration in coal. In Polish coal deposits these elements are marked very rarely $(\mathrm{Sb})$ or aren't marked at all (Bi). Bismuth (Bi) and stibnite ( $\mathrm{Sb}$ ) are called heavy metals. They have high mutual geochemical affinity, but with a different toxicity of their compounds for human body. Sb compounds cause chronic poisoning of the body, by contrast the compounds of Bi contrary, are used in medicine, among others, for the treatment of skin blemishes, they are a major component of surgical dressings, and drugs to combat gastroenterology diseases caused by bacteria Helicobacter pylori (Szczygieł, 2009). Some of the Bi compounds are widely used in industry. They are used among other as catalysts for olefin metathesis reaction that leads to higher octane gasoline. The Bi compounds are used also in the conversion of methane to higher hydrocarbons that can be used as a fuel for internal combustion engines. (Vogt et al., 2008).

\section{The methodology of research}

The study involved 30 samples taken from Chełm and Bogdanka deposits in LCB (Fig. 1). The samples from Chełm deposit come from 378, 382, 385, 387, 389, 391 and 394 seams and were identified in cores from 7 boreholes (Cyców IG-5, Cyców IG-6, Dorohucza IG-4, Dorohucza IG-6, Dorohucza IG-8, Syczyn IG-2 and Syczyn IG-3). The Polish Geological Institute in Warsaw (PIG) have drilled the boreholes, collected and submitted the samples for tests. Six samples of seam's coal were obtained from Bogdanka deposit. Three samples came from 382 and 385/2 seams (according to the PN-G-04501:1998 standard). The average carbon samples for the petrographic tests were prepared from the raw coal samples (according to the PN-ISO 7404-2:2005 standard). The analytical average samples of coal (according to the PN-G-04502:2014-11 standard) and average fly ash samples for the chemical tests (according to the PN-77/G04528/00 standard) were also prepared. In coal samples the content of maceral groups - according to the PN-ISO 7404-3:2001 standard: vitrinite $(V t)$, liptinite $(L)$ and inertinite $(I)$ - was determined. The mineral content was also determined. These analyzes were performed by studying the white reflected light using a Zeiss Axio Imager D1m light microscope. By using the X-ray diffraction (XRD) and microscopic reflectance methods the content of mineral groups in the coal was determined (Table 1). After those tests the content of the ash (obtained after burning coal samples at temp. $525^{\circ} \mathrm{C}$ ) according to the Swanson and Huffman (1976) assumptions was assessed. Using the method of inductively coupled plasma emission spectrometry (ICP - ES), the contents of Bi and $\mathrm{Sb}$ in the coal ash was determined. The content of elements in the coal ash was then calculated to their content in analytic state coal, and the results are given in Table 2 and in Fig. 2-4. Using the Scanning Electron Microscopy-Energy Dispersive Spectroscopy (SEM-EDS), the places of $\mathrm{Bi}$ and $\mathrm{Sb}$ occurrences were identified in some coal grains (Fig. 5). 


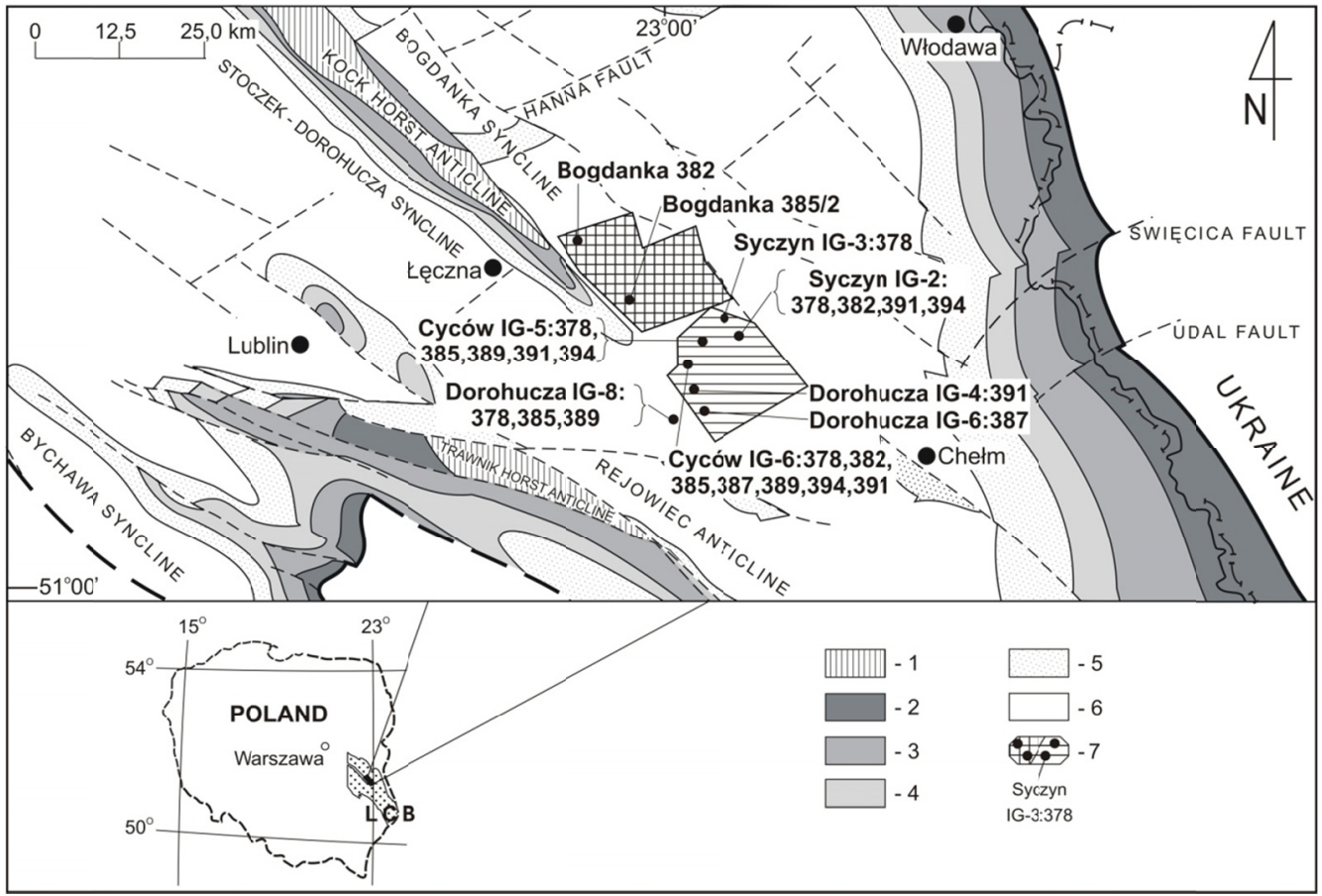

Fig. 1. The location of coal sampling points against geological LCB map (after Porzycki \& Zdanowski, 1995) 1 - Devonian, 2 - Huczwa Formation, 3 - Terebin Formation, 4 - Dęblin Formation, Bug Beds, 5 - Dęblin Formation, Kumów Beds, 6 - Lublin Formation and Magnuszew Formation, 7 - location of the places from where coal samples were taken, boreholes (Syczyn IG-1), marker coal seams (378)

Using the $\chi^{2}$ Pearson and Kolmogorov-Smirnov $(p=0.05)$ tests it was found that the content of petrographic and geochemical components in coal are normally distributed and the value of the geometric mean estimates best the average value (Table 2). To find a relationship between the ash content and the content of $\mathrm{Bi}$ and $\mathrm{Sb}$ in coal and coal ash, and between the content of $\mathrm{Bi}$ and $\mathrm{Sb}$ in coal, and the content of 32 other designated elements in the tested coal (Ag, $\mathrm{Al}, \mathrm{As}, \mathrm{Ba}$, $\mathrm{Be}, \mathrm{Ca}, \mathrm{Cd}, \mathrm{Co}, \mathrm{Cr}, \mathrm{Cu}, \mathrm{Fe}, \mathrm{K}, \mathrm{La}, \mathrm{Mg}, \mathrm{Mn}, \mathrm{Mo}, \mathrm{Na}, \mathrm{Nb}, \mathrm{Ni}, \mathrm{P}, \mathrm{Pb}, \mathrm{Sc}, \mathrm{Sn}, \mathrm{Sr}, \mathrm{Th}, \mathrm{Ti}, \mathrm{U}, \mathrm{V}, \mathrm{W}$, $\mathrm{Y}, \mathrm{Zn}, \mathrm{Zr}$ ), the value of Pearson correlation coefficient was calculated. After this step the linear regression coefficients of determination $R^{2}$ for the wanted relations were calculated. Verification of the linear regression model was carried out using $\mathrm{F}$ - Snedecor test with confidence level of $\alpha=0.05$ and using the $t$ Student test. The significance of the correlation coefficients for the level of significance $<0.05$ was verified. The statistically significant Pearson correlation coefficients - with value of $> \pm 0.35$ - are given in Table. 3 .

In interpretation of the data it was assumed that the correlation coefficients with values from +0.35 to +1.00 may indicate the relationship of $\mathrm{Bi}$ and $\mathrm{Sb}$ with the mineral substance, and the values of -0.35 to -1.00 may indicate the relationship between $\mathrm{Bi}$ and $\mathrm{Sb}$ with the organic substance of coal. In order to verify this assumption and to determine which part of the trace element concentration is associated with the organic and inorganic part of coal the RS function of distribution concentration was used. This function - developed by Marczak (1985) - expresses 
the dependence of element content in the ash, from the ash content in coal. Its suitability for such a determination has previously been empirically confirmed (Lewińska-Preis et al., 2009; Parzentny, 1994). Equation (1) describes this dependence and has the following form:

$$
C_{A}=C_{o} \frac{1-A}{1}+k A+C_{m}
$$

where:

$C_{A}-$ content of element in coal ash $[\mathrm{g} / \mathrm{Mg}]$,

$A$ - content of ash in coal, expressed as mass fraction, in the value of 0 to 1 ,

$C_{o}$ - element content $[\mathrm{g} / \mathrm{Mg}]$ per unit of weight of organic matter,

$k$ - coefficient expressing the increase in the content of the element in coal ash $[\mathrm{g} / \mathrm{Mg}]$, associated with the increase in the ash content by one unit,

$C_{m}-$ content of elelment in coal ash $[\mathrm{g} / \mathrm{Mg}]$ with $A=0-$ limit content,

The first two values $\left(A\right.$ and $C_{A}$ ) were determined experimentally, and other were obtained by solving equation (1). The calculation results are given in Table 3.

\section{Tests results and interpretation}

\subsection{Petrographic content of coal}

Semi-bright coal with epigenetic veins of pirite and marcasite and syngenetic layers of kaolinite clay occurs most frequently in examined coal seams. The petrographic content of coal (Tab. 1) is close the petrographic composition of Paleozoic coals in the North Atlantic

Petrographic composition (\% vol.) and vitrinite reflectance (\%) of coal from LCB

\begin{tabular}{|l|c|}
\hline \multicolumn{1}{|c|}{ Component } & Study area \\
\hline Vitrinite reflectance & 0.64 \\
\hline Coal ash content & 13.91 \\
\hline Vitrinite $(V t)$ & $57.0 / 63.3^{*}$ \\
\hline Liptinite $(L)$ & $23.2 / 25.7^{*}$ \\
\hline Inertinite $(I)$ & $9.9 / 11.0^{*}$ \\
\hline Mineral matter, summary & 9.9 \\
\hline Clay minerals** & 4.6 \\
\hline Quartz & 2.6 \\
\hline Microcline & $\mathrm{sg}$ \\
\hline Siderite & 0.2 \\
\hline Dolomite+ankerite+calcite & 0.8 \\
\hline Jarosite & $\mathrm{sg}$ \\
\hline Pyrite+marcasite & 1.7 \\
\hline Chalcopirite+galene+sphalerite & $\mathrm{sg}$ \\
\hline
\end{tabular}

* Petrographic compistion of coal without mineral matter, ** Mineral composition ccording to diminishing participation in coal: kaolinite $>>$ illite, montmorillonite $>$ haloisite, $\mathrm{sg}-$ single grain 
Europe macroregion $(V t=68 \%, L=12 \%, I=20 \%)$, determined by Lopo de Sousa e Vasconcelous (1999). The content of vitrinite in tested coal is comparable with the content of this macerals group in coal from paralic series $(63.8 \%)$ of USCB, determined by Jurczak-Drabek (1996). In accordance to International Classification of Coal Seams (International Classification of Seam Coals, Final Version, 1995), the tested coal was classified as semi carbonated ortobitumic coal (type C).

\subsection{Volatility of $\mathrm{Bi}$ and $\mathrm{Sb}$ content in coal}

The average contents of $\mathrm{Bi}$ and $\mathrm{Sb}$ in tested $\mathrm{LCB}$ coal for $\mathrm{Bi}$ is low and for $\mathrm{Sb}$ is close to the Clark value of coal (Table 2). The content of $\mathrm{Bi}$ and $\mathrm{Sb}$ in coal generally increases form the younger to the older seams (Fig. 2). Also significant differences in the content of Bi and $\mathrm{Sb}$ in coal (Fig. 3) in the profile of some singular coal seams were observed. The content of Bi in coal

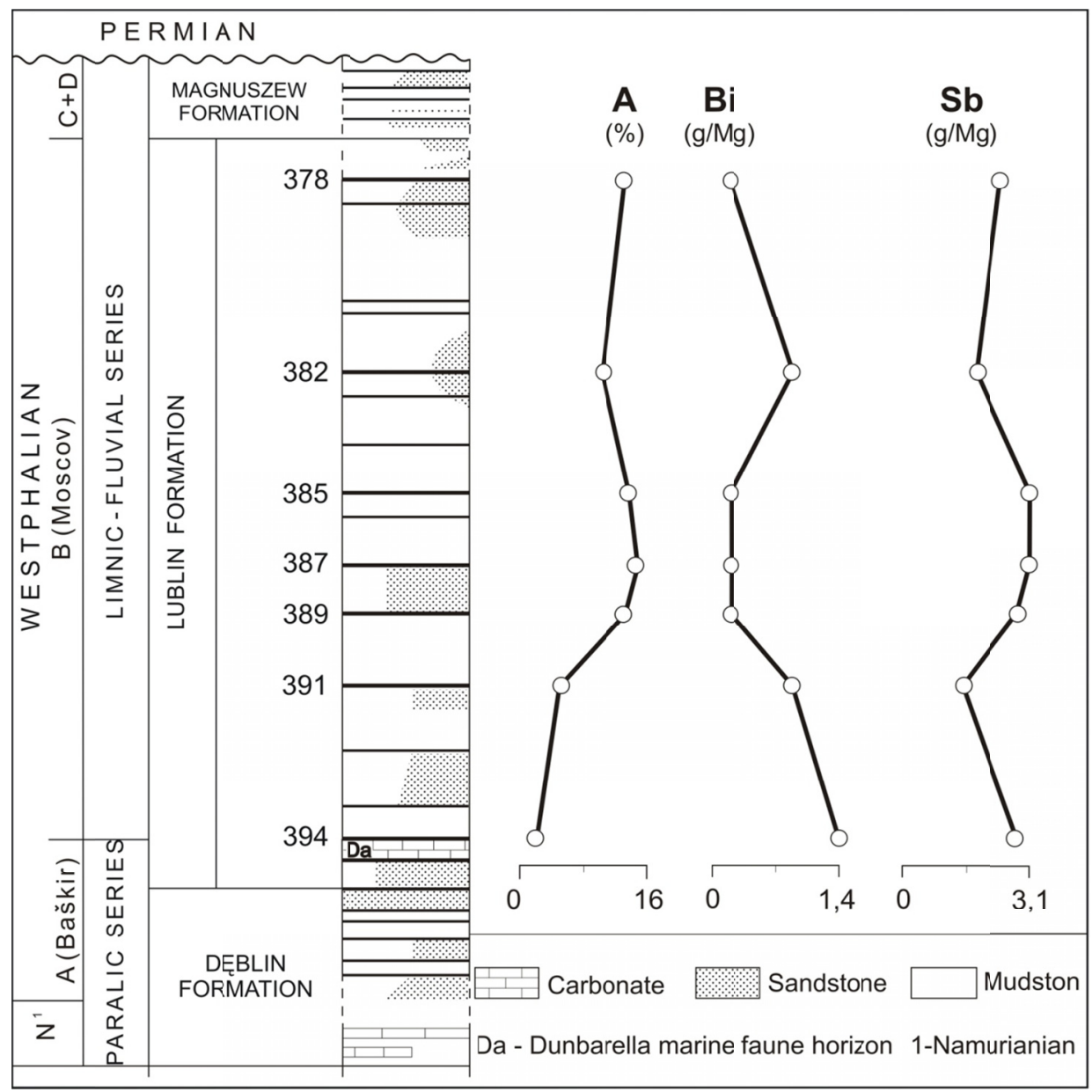

Fig. 2. Ash (A), bismuth and antimony content in coal seams in profile in LCB 
for the roof part of seam (excluding 378 seam) is generally higher, the ash and Sb content in coal are roughly lower (excluding 378 seam due to the ash content and 391 due to the contents of $\mathrm{Sb}$ ) than in coal from the middle part of seam. According to the low content of Bi i Sb, the potentially most preferred coal for combustion is coal from the floor part of 378 seam.

TABLE 2

$\mathrm{Bi}$ and $\mathrm{Sb}$ content in coal from LCB against the hard coal Clarke values by Ketris and Yudovich (2009)

\begin{tabular}{|c|c|c|c|c|c|}
\hline \hline Element & Range & Arithmetic mean & Geometric mean & Standard deviation & Hard coal Clarke values \\
\hline $\mathrm{Bi}$ & $0.1-2.4$ & 0.6 & 0.4 & 0.6 & $1.1 \pm 0.1$ \\
\hline $\mathrm{Sb}$ & $0.1-6.1$ & 2.2 & 1.5 & 1.3 & $1.00 \pm 0.09$ \\
\hline
\end{tabular}

The enrichment process in rare and trace elements of roof and floor part of seam or only from its roof or floor part in relation to the central part of the seam, occurs according to Yudovich and Ketris (2002) in two steps. This process lasts from the coverage of organic matter by the gangue and up to the end of the coal diagenesis. In a first step, the elements are concentrated on the border of the gangue with roof and floor layer of peat or lignite, having a thickness of about $10 \mathrm{~cm}$. In the second step, the elements slowly diffuse into seam. Although Yudovich and Ketris did not specify how large is the group of elements covered by the

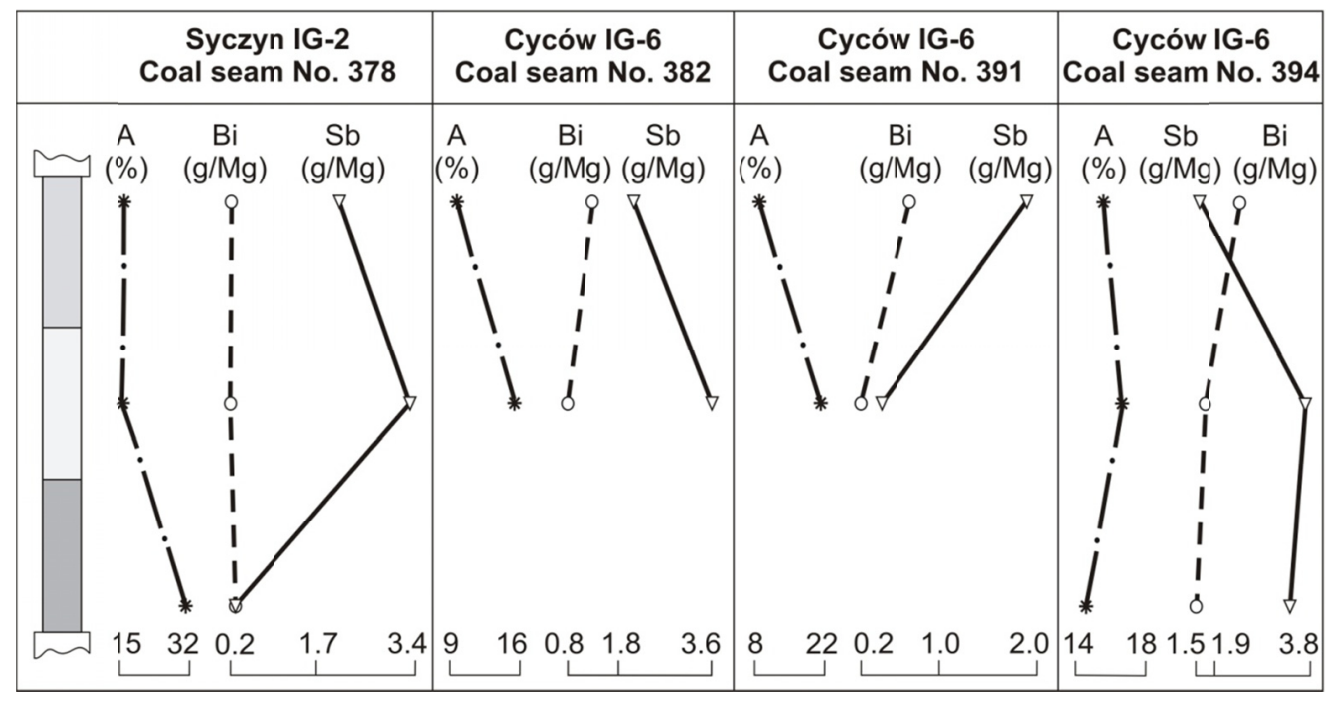

Fig. 3. Bi, Sb and ash (A) content in coal in vertical profile of the same coal seams in LCB

described processes, although in the present article we assumed that these processes could be the cause of $\mathrm{Bi}$ and $\mathrm{Sb}$ enrichment in roof and / or floor part of tested coal seams in LCB. Enrichment of specific parts of coal seams in certain trace elements have been already recorded in LCB (Cebulak, 1983) and in some parts of USCB (Cebulak, 1983; Hanak \& Kokowska-Pawłowska, 2004, 2006; Idzikowski, 1959; Parzentny, 1989). In contrast, the described in this article higher 
ash and $\mathrm{Bi}$ and $\mathrm{Sb}$ content in a coal form the middle part to the lower and upper part of the coal seams is a tendency rarely found. It is caused - according to Yudovich and Ketris (2002) - by:

- desorption of the elements in the outer part of peat and / or lignite due to increase in the $\mathrm{pH}$ of aqueous solutions and / or by diffusion of fulminan trace elements outside the seam and / or;

- disorders of elements sorption and diffusion in the surrounding of gangue interlayers in seams and / or the diffusion of elements from inserts carbonaceous rocks outside the coal seam.

Throughout the LCB a generally larger variety of $\mathrm{Sb}$ than of Bi content in coal was observed (Fig. 4). The content of $\mathrm{Bi}$ in coal throught 378, 382, 385, 387 and 389 seams has low diversity. The values of $\mathrm{Bi}$ content between regions with taken samples from coal seams does not exceed $0,5 \mathrm{~g} / \mathrm{Mg}$. Only the differences between the Bi content in coal from 391 and 394 seam reach value of $1,7 \mathrm{~g} / \mathrm{Mg}$. On the other hand the dispersion of Sb content in coal seams on the extent of LCB is large and increase in the order of seams: $391(1.7 \mathrm{~g} / \mathrm{Mg}), 378(1.6 \mathrm{~g} / \mathrm{Mg}), 382(2.6 \mathrm{~g} / \mathrm{Mg}), 385$ $(3.0 \mathrm{~g} / \mathrm{Mg}), 389$ (3.9 g/Mg) i $387(5.8 \mathrm{~g} / \mathrm{Mg})$.

\subsection{Effect of organic and mineral matter on the content of Bi and $\mathrm{Sb}$ in coal}

The calculated values of the Pearson correlation coefficient - equal to: -0.50 and $-0.60-$ indicates relationship between the increase in the content of $\mathrm{Bi}$ and $\mathrm{Sb}$ in coal ash, and

decrease of the the ash content of coal (Tab. 3). While the p level of significance for t-statistic values lower than of 0.05 means that the values of the correlation coefficient are significantly different from zero. The correlation coefficients - equal to: -0.20 and -0.06 and the significance level $p>0.05$ - indicate an insignificant relationship between the content of $\mathrm{Bi}$ and $\mathrm{Sb}$ in coal and ash content. These dependencies may indicate a dominant influence of organic matter on the content of $\mathrm{Bi}$ and $\mathrm{Sb}$ in the examined $\mathrm{LCB}$ coal. This assumption is confirmed by the results of the RS function, according to which the $100 \%$ of $\mathrm{Bi}$ content and $97 \%$ of $\mathrm{Sb}$ content in coal is

$\mathrm{Bi}$ and $\mathrm{Sb}$ distribution between the organic and mineral matter of coal from LCB, determined using RS function and Pearson correlation coefficient $(r)$ between ash content $(A)$ and $\mathrm{Bi} \mathrm{Sb}$ content in coal and coal ash $\left(C_{B i}, C_{S b}\right)$

\begin{tabular}{|c|c|c|c|c|c|}
\hline \multirow{2}{*}{ Element } & \multicolumn{2}{|c|}{ RS-Organic matter } & RS-Mineral matter & \multirow{2}{*}{$\boldsymbol{r}\left(\boldsymbol{A} / \boldsymbol{C}_{\boldsymbol{B} \boldsymbol{i}}, \boldsymbol{C}_{\boldsymbol{S b}}\right)$} \\
\cline { 2 - 5 } & $\mathbf{g} / \mathbf{M g}$ & $\mathbf{\%}$ & $\mathbf{g} / \mathbf{M g}$ & $\mathbf{\%}$ & \multicolumn{1}{c}{} \\
\hline In coal ash & 100.00 & 0.00 & 0.00 & $-0.50(p=0.005)$ \\
\hline $\mathrm{Bi}$ & 4.56 & 97.40 & 0.44 & 2.60 & $-0.60(p=0.000)$ \\
\hline $\mathrm{Sb}$ & 16.54 & 100.00 & 0.00 & 0.00 & $-0.20(p=0.289)$ \\
\hline In coal & 0.63 & 97.46 & 0.06 & 2.54 & $-0.06(p=0.761)$ \\
\hline $\mathrm{Bi}^{*}$ & 2.30 & $\mathrm{Sb}^{*}$ &
\end{tabular}

* Correlation coefficient $(r)$ for the other depending: $r \mathrm{Bi}-\mathrm{As}=0.48 ; r \mathrm{Bi}-\mathrm{Fe}=0.70 ; r \mathrm{Bi}-\mathrm{Mn}=0.60$; $r \mathrm{Bi}-\mathrm{Mo}=0.48 ; r \mathrm{Sb}-\mathrm{Cu}=0.48 ; r \mathrm{Sb}-\mathrm{Mo}=0.48$

* Współczynniki korelacji $(r)$ dla innych zależności: $r \mathrm{Bi}-\mathrm{As}=0.48 ; r \mathrm{Bi}-\mathrm{Fe}=0.70 ; r \mathrm{Bi}-\mathrm{Mn}=0.60$; $r \mathrm{Bi}-\mathrm{Mo}=0.48 ; r \mathrm{Sb}-\mathrm{Cu}=0.48 ; r \mathrm{Sb}-\mathrm{Mo}=0.48$ 


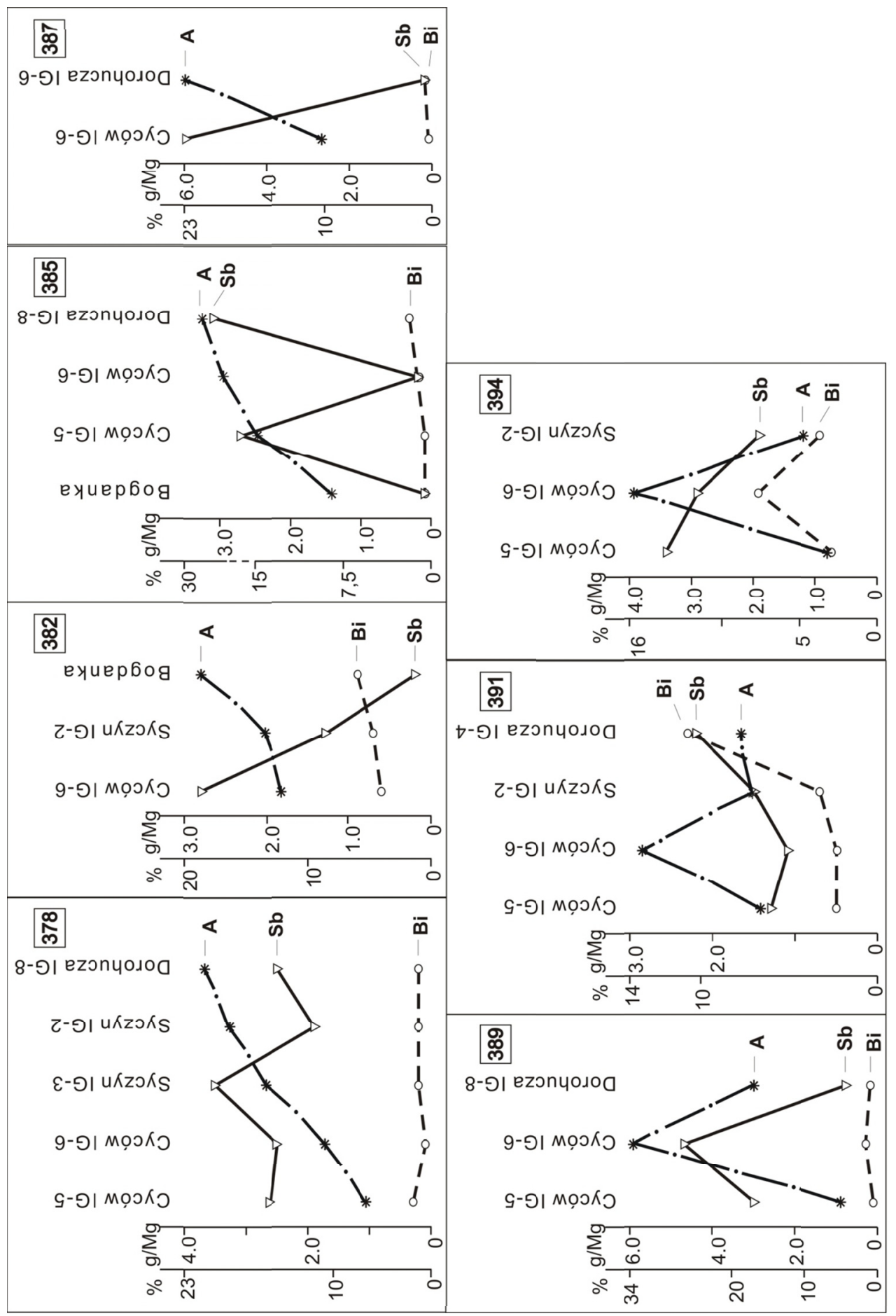


derived from an organic matter. There was also a correlation relationship between the content of $\mathrm{Bi}$ and the content of $\mathrm{As}, \mathrm{Fe}, \mathrm{Mn}$ and $\mathrm{Mo}$ in the coal and between the Sb content and the content of $\mathrm{Cu}$ and Mo in coal. This indicates the possibility of organic matter coexistence in the LCB coal.

The observations of surface of the coal samples with an reflected light optical microscope and using a scanning electron microscope (SEM-EDS), did not reveal the presence of a Bi and $\mathrm{Sb}$ mineral inclusions in macerals, or admixtures of these elements in sulfide, sulfate, carbonate and clay minerals (Fig. 5). The presence of a homogeneous Bi and $\mathrm{Sb}$ mineral was not observed. There were only few complex peaks identifying the elements, as a result of $\mathrm{Bi}$ and $\mathrm{Sb}$ peaks compilation with the peaks of the main elements of organic matter $(C, O)$ in a few grains of semifuzynite with fuzynite (Fig. 5). These macerals were located in a few cells with area lower than $5 \mu \mathrm{m}$ and were impregnated with pyrite or clay minerals. These findings indicate that Bi and $\mathrm{Sb}$ may be distributed in some macerals and minerals in coal, but because of the vast volume and

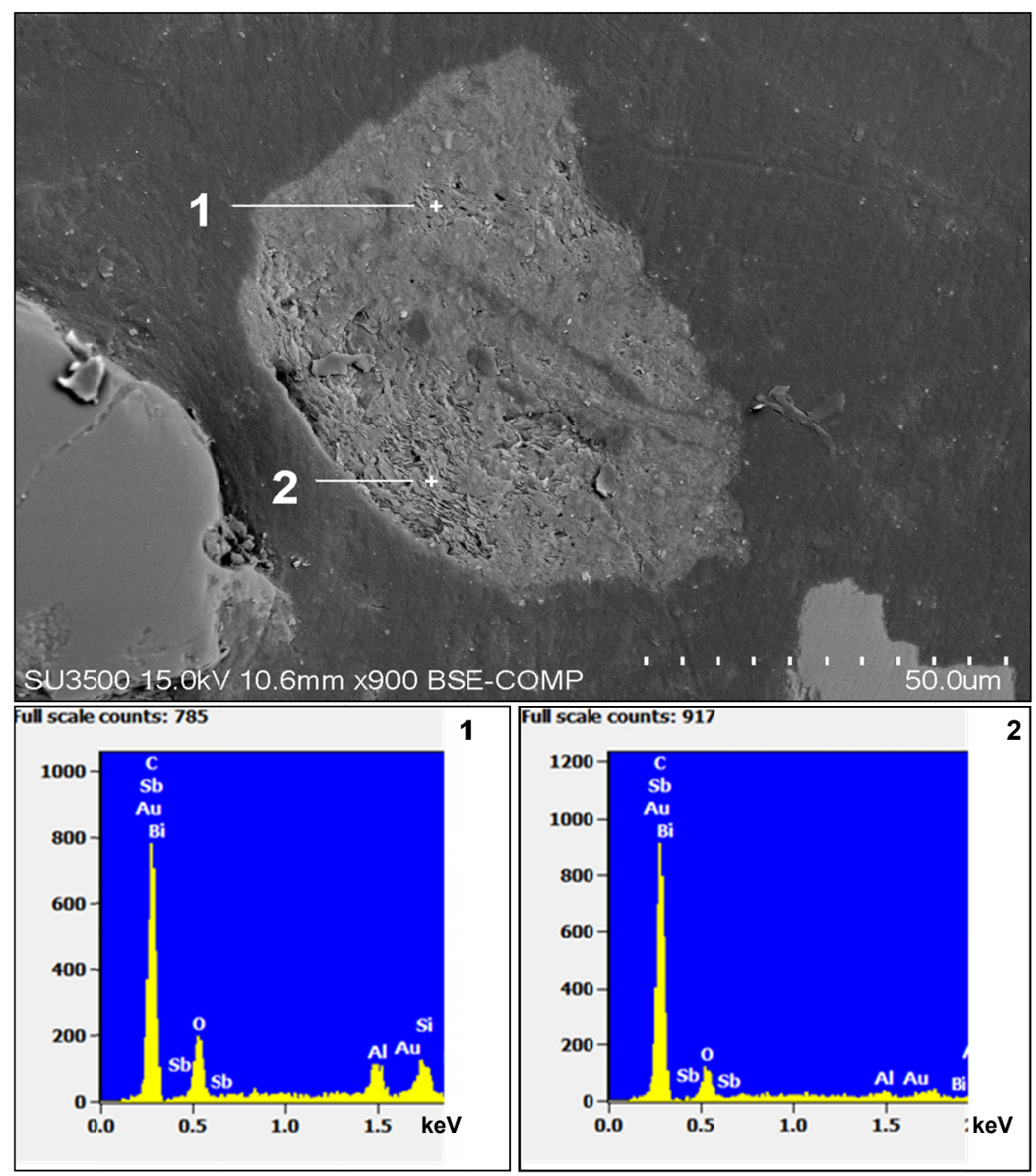

Fig. 5. Bi and $\mathrm{Sb}$ in semifusinite (1) and fusinite (2) determined by SEM-EDS 
weight of the coal's macerals over the mineral substance, the organic substance has the greatest or only impact on the content of these elements in the coal.

The compound of elements with the organic matter is generally detrimental to the environment when using this coal for combustion. Discussed $\mathrm{Bi}$ and $\mathrm{Sb}$ elements in the temperature range $327^{\circ} \mathrm{C}-1127^{\circ} \mathrm{C}$ easily evaporates in furnaces and rapidly condenses on the particles and enriches the phase of litophile elements as, among others: $\mathrm{K}, \mathrm{Ca}, \mathrm{Na}, \mathrm{Mg}, \mathrm{Ti}$ (Ratafia-Brown, 1994). Elements $\mathrm{Bi}$ and $\mathrm{Sb}$ are characterized by a relatively low value of ionization potential and a low melting and evaporation point. Therefore, they can be easily released into the atmosphere as volatile compounds and also $\mathrm{Bi}$ and $\mathrm{Sb}$ condenses on the smallest fly ash particles in the atmosphere and may be included in the content of particulate matter

\section{Conclusions}

1. The average contents of $\mathrm{Bi}$ and $\mathrm{Sb}$ in LCB coal are generally low and are close to the Clark value for bituminous coal:

1.1. the content of $\mathrm{Bi}$ i Sb in LCB coal generally increases from younger to older seams;

1.2. the content of $\mathrm{Bi}$ in coal for the roof part of seam is generally higher and the ash and $\mathrm{Sb}$ content in coal are roughly lower than in coal from the middle part of seam;

1.3. the content of $\mathrm{Bi}$ in coal throught $378,382,385,387$ and 389 seams has a low diversity. The values of $\mathrm{Bi}$ content between different parts of basin does not exceed $0.5 \mathrm{~g} / \mathrm{Mg}$. Only the differences between the Bi content in coal from 391 and 394 seam reach value of $1.7 \mathrm{~g} / \mathrm{Mg}$. The dispersion of Sb content in coal on the extent of LCB increase in the order of seams: $391(1.7 \mathrm{~g} / \mathrm{Mg}), 378(1.6 \mathrm{~g} / \mathrm{Mg}), 382(2.6 \mathrm{~g} / \mathrm{Mg})$, $385(3.0 \mathrm{~g} / \mathrm{Mg}), 389(3.9 \mathrm{~g} / \mathrm{Mg})$ i $387(5.8 \mathrm{~g} / \mathrm{Mg})$.

2. The biggest influence on the content of $\mathrm{Bi}$ and $\mathrm{Sb}$ in LCB coal is probably organic matter in which these elements are scattered and do not form homogeneous minerals.

\section{References}

Bojakowska I., Pasieczna A., 2007. Arsen i antymon $w$ węglach kamiennych i brunatnych ze złóz polskich. Ochrona Środowiska i Zasobów Naturalnych, Vol. 31, p. 522-526.

Cebulak S., 1983. Determination of geochemical components of coal from the point of view of full utilization and environmental preservation. [W:] Bojkowski, K i Porzycki, K. red. Geological problems of coal basins in Poland. Geological Institute Warsaw, p. 335-361.

Cebulak S., Różkowska A., 1983. Korelacja pokładów węgla w Centralnym Rejonie Węglowym Lubelskiego Zagłębia Weglowego na podstawie badań geochemicznych. Kwartalnik Geologiczny, Vol. 27, Nr 1, p. 25-40.

Hanak B., Kokowska-Pawłowska M., 2004. Zróżnicowanie zawartości pierwiastków śladowych i podrzędnych w skałach płonnych $i$ w popiołach węla z pokładu 620. Zeszyty Naukowe Politechniki Śląskiej, seria Górnictwo, Nr 260, p. $155-165$.

Hanak B., Kokowska-Pawłowska M., 2006. Zmienność zawartości pierwiastków śladowych w litotypach węgla i ich popiołach na tle profilów pokładu $630(G Z W)$. Gospodarka Surowcami Mineralnymi, Vol. 22, Zeszyt specjalny Nr 3, p. 69-77.

Idzikowski A., 1959. O występowaniu niektórych mikroelementów w węglach kamiennych warstw rudzkich $i$ siodtowych na Górnym Śląsku. Archiwum Mineralogiczne, Vol. 23, Nr 2, p. 272-350. 
International Classification of Seam Coals, Final Version, 1995. Economic Commission for Europe, Committee On Energy, Working Party On Coal, Fifth Session, Genève.

Jurczak-Drabek A., 1996. Atlas petrograficzny złóż węgla kamiennego Górnośląskiego Zagtębia Węglowego, 1:300 000. Państwowy Instytut Geologiczny, Warszawa.

Ketris M.P., Yudivich Ya.E., 2009. Estimations of Clarkes for Carbonaceous biolithes: World avarages for trace element contents in black shales and coals. International Journal of Coal Geology, Vol. 78, p. 135-148.

Lewińska-Preis L., Fabiańska M.J., Ćmiel S., Kita, A., 2009. Geochemical distribution of trace elements in Kaffioyra and Longyearbyen coals, Spitsbergen, Norway. International Journal of Coal Geology, Vol. 80, p. 211-223.

Lopo de Sousa e Vasconcelos 1999. The petrographic composition of world coals. Statistical results obtained from a literature survey with reference to coal type (maceral composition). International Journal of Coal Geology, Vol. 40, p. $27-58$.

Marczak M., 1985. Geneza i prawidłowości występowania pierwiastków śladowych w węlach złoża Chetm w Lubelskim Zagtębiu Węglowym. Prace Naukowe Uniwersytetu Śląskiego, Nr 748, p. 1-109.

Marczak M., Lewińska L., 1982. Molibden w węglach kamiennych złoża Chetm (Lubelskie Zagłębie Węglowe). Prace Naukowe Uniwersytetu Śląskiego, seria Geologia, Vol. 6, p. 22-32.

Marczak M., Parzentny H., 1985. Geochemiczna i ekologiczna ocena węgli złoża Chełm o podwyższonych $i$ wysokich koncentracjach ołowiu. Przegląd Geologiczny, Vol. 33, Nr 12, p. 680-683.

Marczak M., Parzentny H., 1989. Stężenia kadmu jako kryterium ekologicznej oceny węgli złoża Chetm w Lubelskim Zagłębiu Węglowym. Przegląd Geologiczny, Vol. 37, Nr 5, p. 272-275.

Parzentny H., 1989. Różnice w zawartości i sposobie związania niektórych pierwiastków w węglu Górnośląskiego Zagłębia Węglowego w profilu pojedynczego pokładu. Przegląd Górniczy, Vol. 45, Nr 4, p. 17-21.

Parzentny H., 1994. Lead distribution in coal and coaly shales in the Upper Silesian Coal Basin. Geological Quaterly, Vol. 38, p. 43-58.

Parzentny H., 2009. Srebro, cyna $i$ wolfram $w$ weglu z formacji Lublina (westfal B) w Lubelskim Zagłębiu Węglowym $(L Z W)$. Gospodarka Surowcami Mineralnymi - Mineral Resources Management, Vol. 25, Nr 1, p. 147-167.

PN-G-04501:1998. Węgiel kamienny i antracyt. Pobieranie próbek pokładowych bruzdowych.

PN-G-04502:2014-11. Węgiel kamienny i brunatny. Pobieranie i przygotowanie próbek do badań laboratoryjnych. Metody podstawowe

PN-ISO 7404-2:2005. Metody analizy petrograficznej węgla kamiennego (bitumicznego) i antracytu. Część 2: Metoda przygotowania próbek węgla

PN-77/G-04528/00. Paliwa stale. Oznaczanie składu chemicznego popiołu. Przygotowanie próbki popiołu i roztworów do badań

PN-ISO 7404-3:2001. Metody analizy petrograficznej węgla kamiennego (bitumicznego) i antracytu. Część 3: Metoda oznaczania składu grup macerałów

Porzycki J., Zdanowski A., 1995. Coal deposits, Lublin Coal Basin. In: The carboniferous system in Poland. [W:] Zdanowski, A. i Żakowa H. red.). Papers of the Polish Geological Institute, Nr 148, p. 159-164.

Ratafia-Brown J.A., 1994. Overview of trace elements partitioning in flam es and furnaces of utility coal-fired boilers. Fuel Processing Technology, Vol. 39, p. 139-157.

Strugała A., Makowska D., Bytnar K., Rozwadowska T., 2014. Analiza zawartości wybranych pierwiastków krytycznych w odpadach z procesu wzbogacania węgla kamiennego. Polityka Energetyczna - Energy Policy Journal, Vol. 17, p. $77-89$.

Swanson V.E., Huffman C., 1976. Guidelines for sample collecting and analytical methods used in U.S. Geological Survey for determining chemical composition of coal. Geological Survey Circular, Nr 735.

Szczygieł Ł., 2009. Medyczne zastosowania związków bizmutu. Gazeta Farmaceutyczna, Vol. 4, p. 36-38.

Vogt O., Ogonowski J., Litawa B., 2008. Wpływ właściwości kwasowo-zasadowych i redukowalności katalizatorów Bo-Si-O modyfikowanych wybranymi jonami metali na ich aktywność w procesie $\mathrm{OCM}-\mathrm{CO}_{2}$. Czasopismo Techniczne Chemia, Vol. 13, z. 1-Ch, p. 149-154.

Xu R., Yan R., Zheng C., Qiao Y., 2003. Status of trace element emission in a coal combustion process: a review. Fuel Processing Technology, Vol. 85, p. 215-237.

Yudovich Ya., E., Ketris M.P., 2002. Neorganičskoe veščestvo ugley. Russian Academie of Sciences Ural Division Ekaterinburg, p. 1-423. 